\title{
Long-term application of the organic and inorganic pesticides in vineyards: Environmental record of past use
}

\author{
Carla Patinha ${ }^{a,}{ }^{*}$, Nuno Durães ${ }^{a}$, Ana Cláudia Dias ${ }^{a}$, Pedro Pato ${ }^{b}$, Rita Fonseca ${ }^{c}$, \\ Ana Janeiro ${ }^{\mathrm{d}}$, Fernando Barriga ${ }^{\mathrm{d}}$, Amélia Paula Reis ${ }^{\mathrm{a}}$, Armando Duarte ${ }^{\mathrm{b}}$, \\ Eduardo Ferreira da Silva a ${ }^{\mathrm{a}}$, António Jorge Sousa ${ }^{\mathrm{e}}$, Anabela Cachada ${ }^{\mathrm{b}, \mathrm{f}}$ \\ ${ }^{a}$ GEOBIOTEC, Department of Geosciences, University of Aveiro, Campus de Santiago, 3810-193 Aveiro, Portugal \\ ${ }^{\mathrm{b}}$ CESAM, Department of Chemistry, University of Aveiro, Campus de Santiago, 3810-193 Aveiro, Portugal \\ ' Évora Geophysics Center, Department of Geosciences, School of Sciences and Technology, University of Évora, 94, Évora, Portugal \\ ${ }^{\mathrm{d}}$ Department of Geology and CREMINER LA/ISR, Faculty of Sciences, University of Lisbon, Campo Grande, 1794-016 Lisbon, Portugal \\ e CERENA - Centre for Natural Resources and the Environment, Instituto Superior Técnico, University of Lisbon, 1049-001 Lisbon, Portugal \\ ${ }_{\mathrm{f}}^{\mathrm{f}}$ Interdisciplinary Center of Marine and Environmental Research (CIIMAR/CIMAR), Terminal de Cruzeiros do Porto de Leixões, Avenida General Norton de \\ Matos, S/N 4450-208 Matosinhos, Portugal
}

\section{A R T I C L E I N F O}

\section{Article history:}

Received 31 January 2017

Received in revised form

8 May 2017

Accepted 11 May 2017

Available online 11 May 2017

Editorial handling by Prof. M. Kersten.

\section{Keywords:}

Copper

DDT

Fungicides

Vineyards

Douro region

\begin{abstract}
A B S T R A C T
Areas such as Douro Demarcated Region (Portugal), where vineyards are frequently located on steep slopes of narrow valleys, can be particularly sensitive to runoff and erosion processes. These particular conditions are expected to enhance the transport of pollutants, acting as a potential source of contamination to freshwater systems. The intense vine cultivation in this region includes decades of pesticides application, that have resulted in the accumulation of these chemicals and its degradation products in the vineyards soils and sediments. Residues of several pesticides related to agricultural activities were found in soils, with older vineyards showing higher levels of $\mathrm{Cu}$ and banned insecticides (such as DDT). The metabolite 4,4-DDE was the compound found at higher levels in soils and in sediments. The relatively high levels in more recent sediments suggest that soils are still a source of contamination. Levels of currently used pesticides were low, which is related with their physicochemical properties, the application period, and climacteric conditions.
\end{abstract}

(c) 2017 Elsevier Ltd. All rights reserved.

\section{Introduction}

The viticulture and wine tourism represent an important economic add value and a cultural significance in many countries. Wine is part of the culture of many countries, an element of wellbeing either as a form of convivial or by its health benefits, at least in the opinion of many of its defenders (Bisson et al., 2002). In Portugal, viticulture stands for approximately $7 \%$ of the national agricultural sector (Meneses et al., 2014), therefore, an important contributor to the national economy of a small country like this.

Notwithstanding, a large number of inorganic and synthetic organic pesticides are frequently applied in viticulture. These pesticides belong to different chemical classes, which means that physicochemical properties and, consequently, its behavior (transport, mobility, and fate) in the environment can be considerably different. Therefore, the potential hazards posed by their use are highly variable and the intensive use of pesticides in vineyards is currently a cause of public concern, mainly due to the adverse health effects, which can be found in water and wine products used for human consumption (Rabiet et al., 2010).

The century-old practice of organic and inorganic (especially Cu-based) pesticides use for control and protective measure against grapevine diseases, insect damage, and weed competition in vineyards has led to long-term accumulation of $\mathrm{Cu}$ and other chemical substances in vineyard soils and other environmental compartments (Besnard et al., 2001; Hildebrandt et al., 2008;

\footnotetext{
* Corresponding author.

E-mail address: cpatinha@ua.pt (C. Patinha).
} 
Komárek et al., 2010). It was estimated that less than $0.1 \%$ of the pesticide applied to crops actually reaches the target pest, whereas the remnant easily enters into the environment, contaminating soil, water and air, where it can poison or otherwise adversely affect non-target organisms (Pimentel and Levitan, 1986). For example, levels of herbicides and fungicides higher than the EU regulatory limit set for surface waters, have been reported nearby vineyard areas from Spain (Hildebrandt et al., 2008) or France (Rabiet et al., 2010).

Since the end of the 19th century, Cu-based fungicides have been intensively used in Europe to control vine fungal diseases. Contrarily to synthetic organic fungicides that are banned in European organic viticulture, Cu-based fungicides, such as $\mathrm{Cu}(\mathrm{OH})_{2}$, copper oxychloride $3 \mathrm{Cu}(\mathrm{OH})_{2} \cdot \mathrm{CuCl}_{2}, \mathrm{CuSO}_{4}$, and $\mathrm{Cu}_{2} \mathrm{O}$, are allowed and indispensable for organic vine cultivation (EC regulation 473/ 2002). Due to the non-degradable character, $\mathrm{Cu}$ accumulation in vineyard soils exclusively depends in the amount applied in the agroecosystem, which is related to climatic conditions, and well correlated with vineyard ages. Although, $\mathrm{Cu}$ accumulation in soils is greatly affected by physicochemical conditions, which influence its solubility and sorption to soil particles. Copper in soils is mostly associated with soil organic matter (SOM), Fe- and Mn-(hydr)oxides, and to a lesser extent with clay minerals through specific and non-specific adsorption (Parat et al., 2002; Bradl, 2004; FernándezCalviño et al., 2009). Copper can easily reach other compartments (water and sediments) by particle dispersion due to soil erosion, which is favoured in areas with more pronounced reliefs, or solubilized, particularly when low $\mathrm{pH}$ conditions $(\mathrm{pH}<6)$ prevail in soil system (Adriano, 2001; Celardin et al., 2004; Boudesocque et al., 2007; Nóvoa-Muñoz et al., 2007). Management practices can also affect $\mathrm{Cu}$ mobility, as for example the use of organic amendments, which had a direct effect on the retention of $\mathrm{Cu}$ in soil (Besnard et al., 2001).

On the other hand, many of the highly toxic and persistent organic substances have been progressively banned as their hazard has been proven (e.g.: DDT, endosulfan, simazine), while others are being subject of European regulation (European Commission, 2006). Persistent and mobile pesticides can be transported in the environment over long distances to places far from the points of release, turning this issue a global environmental problem. Moreover, these persistent pesticides (or their degradation products) can remain in soils for several years, or even decades, long after their use. Through various dynamic processes they can enter directly in the food chain, or percolate down and reach groundwater reservoirs (Gavrilescu, 2005; Gaw et al., 2006). Indeed, some pesticides are still detectable in surface waters 20 years after their use had been banned (Larson et al., 1997). Nevertheless, the long-term environmental fate of pesticides has been poorly studied (Bundschuh et al., 2014; Sabatier et al., 2014).

In vineyards, such as the ones from Douro region where vines are located on steep slopes, soil erosion has also an important role on the dispersion of pollutants, especially to the nearby aquatic systems. Indeed, sediments are an important sink of contaminants and, whenever the sedimentation conditions permit, sediment cores can be used to evaluate and reconstruct historical contaminant trends in aquatic environments. In particular, dam reservoirs are interesting sites to study the presence and accumulation of pollutants because contaminated particles can eventually become trapped and buried.

Therefore, in order to evaluate the fate of organic and inorganic (Cu-based) pesticides three vineyard areas, with different plantation ages, were studied and the levels of banned and currently used pesticides were assessed. Moreover, with the aim of understanding the legacy left by the long-term pesticides application in this area, the distribution of contaminants in a sediment core from an adjacent dam reservoir was assessed.

\section{Materials and methods}

\subsection{Study area}

The Douro Demarcated Region, where the famous Port wine is produced, covers an area of approximately 250,000 ha in northeastern Portugal, and is considered the oldest demarcated winemaking region in the world (Andersen et al., 2004). Since December 2001, this region is considering an UNESCO's World Heritage Site due to its cultural landscape of outstanding beauty.

The studied area is a small catchment located in the municipality of Lamego, Viseu district. The area englobing the three vines sampled has about $500000 \mathrm{~m}^{2}$, while the entire area, including the core sediment, has about $1400000 \mathrm{~m}^{2}$. The climate of this region is characterized by a mean annual rainfall of $900 \mathrm{~mm}$ and an average temperature of $18{ }^{\circ} \mathrm{C}$. The rainfall variation between the years of 1974 and 2012 are report in Fig. 1, where it is possible to delimit longer periods with high rainfall prevailing condition (1976-1979; 1983-1985; 1987-1989; 1995-1997; 1999-2003; 2006 and 2009-2010). The lowest values were obtaining for the years of 1980, 1982, 1990-1994, 1998, 2005, 2007 and 2012. The drainage basin discharges into an important water reservoir, the Varosa Dam, which collects water from two main rivers, the Varosa and the Balsemão Rivers (Fig. 2). This is an undisturbed reservoir, resulting in more than 40 years of accumulated sediments.

The geology of this area is characterized by a low-grade metasedimentary complex unit, composed by interstratified schists and grauwackes. Locally this metasedimentary unit was intruded by granitic rocks evidencing high kaolinization of feldspars (Teixeira et al., 1969). The most dominant feature of the landscape in this region, with slopes at over $15 \%$, is the terraced vineyards that blanket the countryside. Soils have been created literally by breaking up rocks and are classified as anthrosols (FAO-UNESCO, 1974).

\subsection{Sampling}

Forty-nine soil samples $(0-15 \mathrm{~cm})$ were collected, during September and October 2012, from 3 vineyards with different ages: one recently planted/replanted (V1); other with more than 15 years (V2); and one with more than 50 years (V3) (Fig. 2). Each soil sample is a composite of 2 sub-samples (one collected in the middle of the terrace, near the vine, and the other in the outmost area of terrace). A representative sample of the background of this region, without vine cultivation was collected.

Several sediment cores were collected in the reservoir. The deepest sediment column was obtained at $50 \mathrm{~cm}$. Samples were sliced at each $1 \mathrm{~cm}$ in the first $10 \mathrm{~cm}$, and at each $2 \mathrm{~cm}$ in the remaining. In order to have sufficient amount of sample for the different analysis, a composite sub-sample was obtained by mixing the sediments of the same depth from the different cores. Thus, 31 sub-samples were obtained.

\subsection{Chemical and physicochemical characterization}

Soil and sediment samples were air dried, sieved through a $2 \mathrm{~mm}$ nylon sieve, and well homogenized in order to obtain representative samples for analytical determinations. For chemical analysis, the samples were ground in an agate mortar. For organic pesticides analysis, samples were immediately frozen, lyophilized, sieved through a $2 \mathrm{~mm}$ stainless-steel sieve, and kept at $-20{ }^{\circ} \mathrm{C}$ until the analysis were performed.

The grain size distribution of sand, silt and clay fractions were 


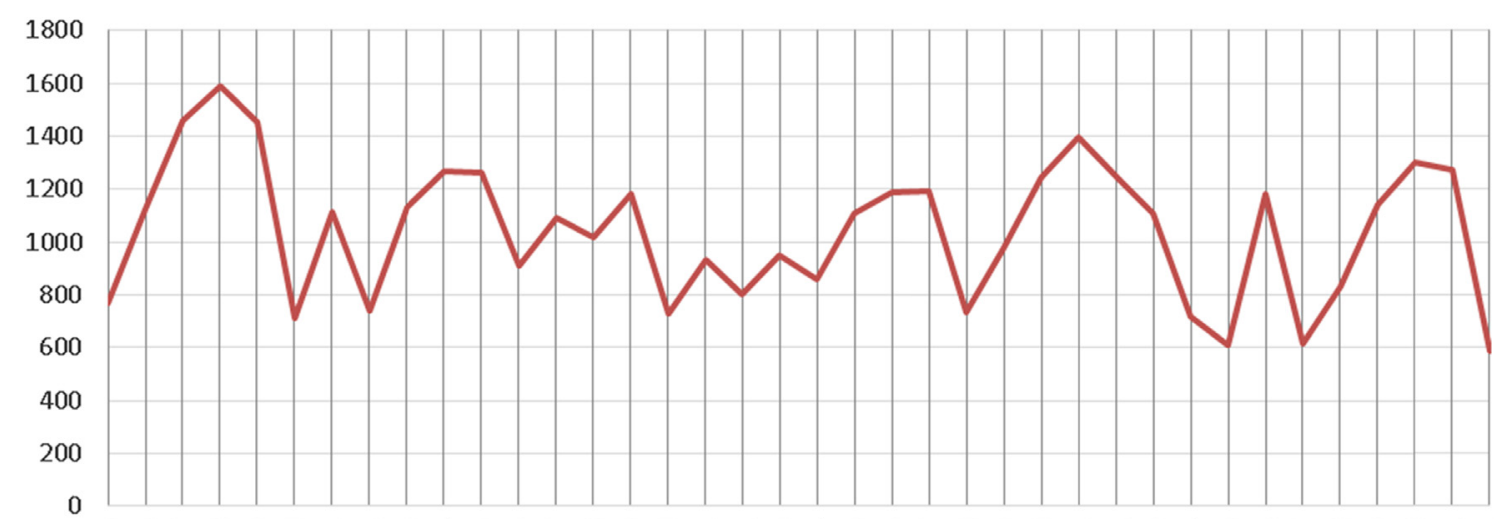

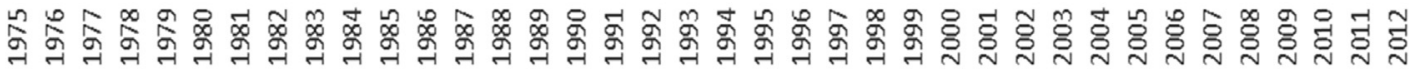

Annual precipitation ( $\mathrm{mm}$ )

Fig. 1. Mean annual rainfall for studied region for the period of 1975-2012 (Source: http://snirh.pt/).

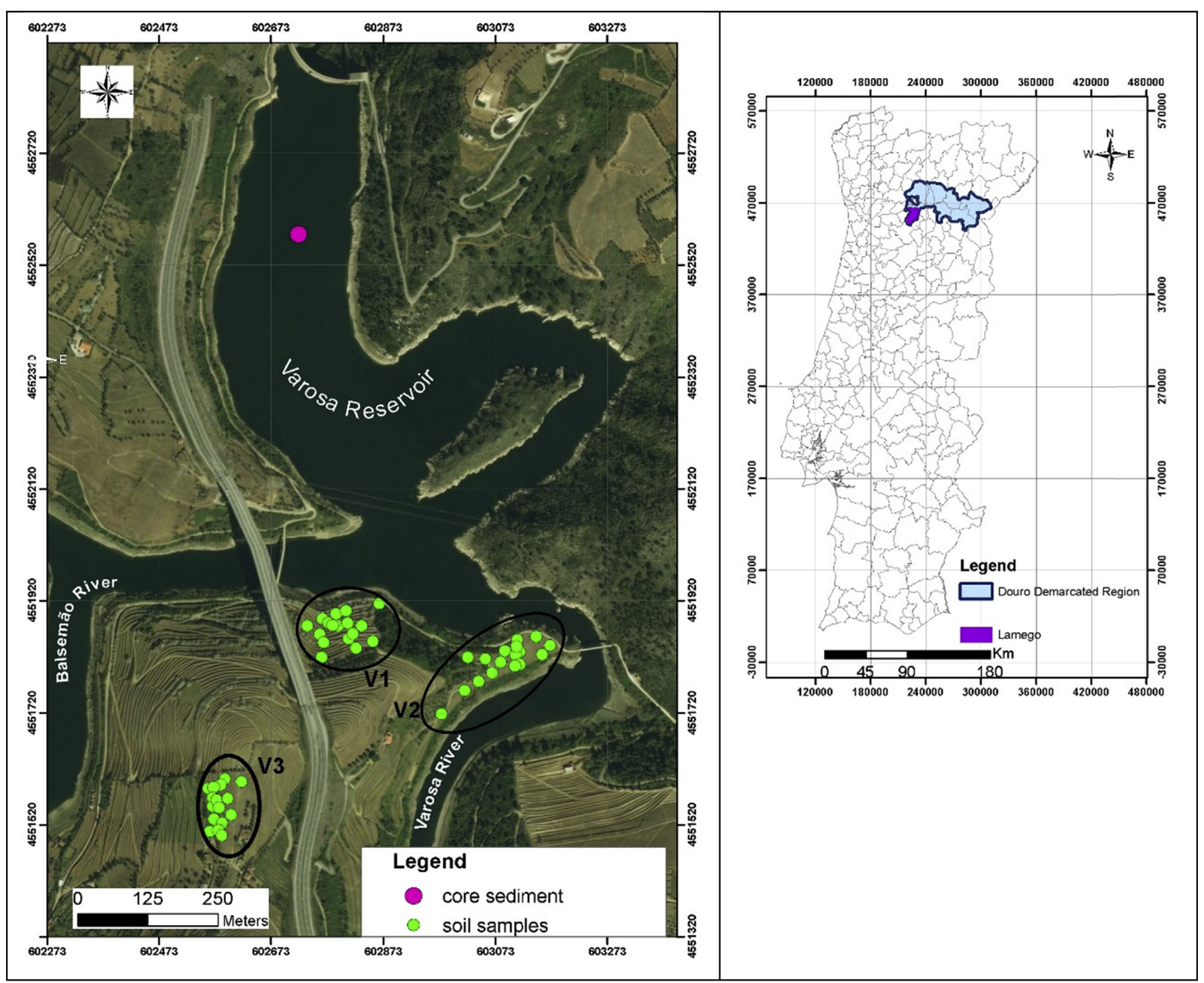

Fig. 2. Study area location and soil sampling site, Douro Demarcated Region - Lamego, Portugal. 
determined only in vineyard soils, using an X-ray grain size analyzer (Sedigraph 5100). All the other physicochemical parameters were determined in both matrixes. The $\mathrm{pH}$ for was measured in a solid:water (1:5) suspension after $24 \mathrm{~h}$ of contact time. The organic carbon (OC), $\mathrm{N}$ and $\mathrm{S}$ were determined using an elemental analyzer Eurovector - EA3000, based on the principle of dynamic flush combustion. Total $\mathrm{P}$ ( $\mathrm{P}_{\text {total }}$ ) was extracted using $\mathrm{H}_{2} \mathrm{SO}_{4} 1 \mathrm{~N}$ after incineration at $550{ }^{\circ} \mathrm{C}$ during $2 \mathrm{~h}$, while available $\mathrm{P}\left(\mathrm{P}_{\text {avail }}\right)$ was extracted using $\mathrm{NH}_{4} \mathrm{Cl} 1 \mathrm{M}$, followed by P colorimetric determination as described by Murphy and Riley (1962). The concentration of $\mathrm{Cu}$ was determined using Inductively Coupled Plasma-Mass Spectrometry (ICP-MS), after an aqua regia digestion, at the ACME Analytical Laboratories of Canada (ISO 9002 Accredited Lab).

The pesticides under analysis were selected according to a survey of the most important and commonly applied to the vineyards of the region. The selection included fungicides (boscalid, folpet, metalaxyl, penconazole, tebuconazole), herbicides (terbutylazine and its degradation product desethylterbutylazine), and insecticides (chlorpyriphos, deltamethrin). Some pesticides currently banned were also included because they are considered priority substances under the scope of Water Framework Directive, and they were commonly used in this region during decades: endosulphan $\left(\alpha\right.$ and $\beta$ ), DDX (4,4' DDE, 2,4 DDT, 4, $4^{\prime}$ DDD, 2,4 DDD, 4,4 DDT), and simazine. Regarding the core sediment samples, only the pesticides considered persistent and immobile (endosulphan and DDTx) were analyzed, as these are the only ones that could give a record of the past use.

Depending on the polarity of the compound, a mixture of hexane:acetone or methanol:water were used for the extraction of pesticides from 15 soil ( 5 in each area) and 18 sediment samples. Extracts were then cleaned-up by Solid Phase Extraction, using Florisil $^{\odot}$ for hexane:acetone extracts and C18 for methanol:water extracts (Caetano et al., 2012; Gonçalves and Alpendurada, 2005). Compounds were quantified by GC-MS, using a ZB-5MS column, and an internal standard calibration.

\section{4. $Q A / Q C$ methodology}

The accuracy and the precision of the analytical methods were performed by including replicates, procedure blanks, and available certified reference materials (for $\mathrm{Cu}$ and persistent pesticides) or fortified samples in each analytical batch. Regarding major and trace elements, replicate analysis of the soil and sediment samples gave an uncertainty of $<10 \%$. The results of blanks analysis were always below detection limit, and recoveries of reference material were within the certified value. For pesticides, replicate analysis of the soil and sediment samples gave an uncertainty of $<25 \%$ for each individual compound. Also for these compounds, results of blanks analysis were always below detection limit, which ranged between 0.2 e $1.0 \mu \mathrm{g} \mathrm{kg}^{-1}$. Recoveries of certified reference material and fortified samples were within the acceptable range: $60-117 \%$.

\subsection{Enrichment factors}

Enrichment factors (EF) are frequently used to assess the degree of metal pollution in sediments (Rahman and Ishiga, 2012; Yao et al., 2013; Islam et al., 2015). The specific metal enrichment can be distinguished based on the relationship between its concentration and suitable concentrations of conservative elements (Rahman and Ishiga, 2012; Yao et al., 2013; Islam et al., 2015).

In this study, EF was calculated for $\mathrm{Cu}$ by normalizing its distribution in the core sediments to a conservative element as pointed by the following equation:
$E F=\frac{\left[\left(C_{C u-s e d}\right) /\left(C_{R-s e d}\right)\right]}{\left[\left(C_{C u-b k}\right) /\left(C_{R-b k}\right)\right]}$

where, $C_{C u}$ - sed and $C_{R}$ - sed are the $C u$ and reference element concentrations in the sediment sample, respectively, whereas $\mathrm{C}_{\mathrm{Cu}-}$ bk and $C_{R}$ - bk are the local background concentrations for $\mathrm{Cu}$ and reference element, respectively.

In this case, $\mathrm{Cu}$ was normalized to $\mathrm{Al}$, since the last is a lithogenic conservative element and a major constituent of clay minerals (main components of schists), and that has been successfully used in numerous studies to distinguish natural and anthropogenic sources of metals (Loska and Danuta, 2003; Franco-Uria et al., 2009; Rahman and Ishiga, 2012). The values of $33900 \mathrm{mg} \mathrm{Al} \mathrm{kg}^{-1}$ and $16.6 \mathrm{mg} \mathrm{Cu} \mathrm{kg}^{-1}$ of soils from the region without influence of vine cultivation were used as reference concentrations for this calculus.

\subsection{Statistical analysis}

Since data did not show a normal distribution (Shapiro-Wilk test), Spearman correlations were used to describe the interactions between the solid phase distribution of physicochemical parameters and $\mathrm{Cu}$. In addition, principal component analysis (PCA) was performed for core sediments samples in order to understand the pattern of interrelationships among selected sediment parameters. The data was log transformed before PCA analysis.

\section{Results and discussion}

\subsection{Physicochemical characterization of vineyard soils}

The vineyard soils from this region result, as previously mentioned, by the schists breaking by man, which result in a high heterogeneity in the particle size distribution, mainly composed by two main groups: the rather coarse particles (gravel size) and the fine particles. These last ones are the most important regarding the soil texture as well as its influence on contaminants dispersion. Thus, despite the slightly higher silt content in the oldest vineyard, few differences were observed between soils samples, being all classified as silt loam. Contrarily, a high variability of physicochemical and chemical parameters was observed in the entire area (Table 1) and within each vineyard (Fig. 4). Such large inter- and intra-site variability could be attributed to management practices (e.g.: the number of vineyard treatments and the spraying methods used).

Although the soils from this region can be considered acidic ( $\mathrm{pH}=5.40$, in the background sample), in vineyard soils $\mathrm{pH}$ values indicate the prevalence of very acidic conditions for the majority of samples $(\mathrm{pH}<5)$ (Table 1$)$. The $\mathrm{pH}$ values changes seem to be related with the vineyard's age (Fig. 3), since a slight decrease in these values is observed with the increasing age of vineyards. Several processes can promote soil acidification, as the leaching of basic ions from the soil profile, microbial activity, and the addition of agrochemicals. In the particular case of vineyards, an important contribution for soil acidification can result from the applications of elemental sulfur $\left(S^{0}\right)$ in vines (Klikocka et al., 2015). In fact, $S$ has been used extensively since long time as a protective measure against crop diseases, especially in the growing season (Griffith et al., 2015). The decrease of soil $\mathrm{pH}$ is mainly observed immediately after $S$ application, because a quite fast oxidation of $\mathrm{S}^{0}$ to $\mathrm{SO}_{4}^{2-}$ promotes the neutralization by salts precipitation (Hinckley et al., 2011). Indeed, recent studies have shown that the majority of the $\mathrm{S}$ applied oxidizes in the first half-hour, with complete oxidation to $\mathrm{SO}_{4}^{2-}$ occurring within 7 days after application (Hinckley et al., 2011; Hinckley and Matson, 2011). 
Table 1

Univariate statistical description of physicochemical and chemical properties of soil vineyard samples.

\begin{tabular}{|c|c|c|c|c|c|c|c|c|}
\hline & $\mathrm{pH}$ & $S$ & OC & $\mathrm{N}$ & $\mathrm{C} / \mathrm{N}$ & $\mathrm{P}_{\text {total }}$ & $P_{\text {avail }}$ & $\mathrm{Cu}$ \\
\hline & & $\left(\mathrm{mg} \mathrm{kg}^{-1}\right)$ & $\left(\mathrm{g} \mathrm{kg}^{-1}\right)$ & $(\%)$ & & $\left(\mathrm{mg} \mathrm{kg}^{-1}\right)$ & $\left(\mathrm{mg} \mathrm{kg}^{-1}\right)$ & $\left(\mathrm{mg} \mathrm{kg}^{-1}\right)$ \\
\hline Min & 3.18 & 100 & 1.9 & 0.015 & 5.8 & 27.1 & bdl & 17.8 \\
\hline Max & 6.56 & 550 & 53 & 0.350 & 21 & 420 & 35 & 211 \\
\hline Mean & 4.41 & 224 & 10.5 & 0.095 & 10.9 & 274 & 9.6 & 79.4 \\
\hline Median & 4.84 & 200 & 8.5 & 0.082 & 10.5 & 282 & 6.7 & 55.9 \\
\hline CV (\%) & 10.8 & 44 & 79 & 62 & 21 & 32.6 & 102 & 70.5 \\
\hline
\end{tabular}

bdl - below detection limit.

The concentrations of $S$ in vineyard soils (mean value of $224 \pm 125 \mathrm{mg} \mathrm{kg}^{-1}$; Table 1) are slightly higher than the background levels ( $150 \mathrm{mg} \mathrm{kg}^{-1}$ ) found for soils of this area. These concentrations are similar to those found in other regions, as the case of the Napa Valley vineyard, where S concentrations range between 275 and $300 \mathrm{mg} \mathrm{kg}^{-1}$ (Hinckley and Matson, 2011), but lower than the levels $\left(326-496 \mathrm{mg} \mathrm{kg}^{-1}\right.$ ) found in four Apulian organic vineyard (Provenzano et al., 2011). Several factors can affect local vineyard $\mathrm{S}$ budgets, as the management practices (S applications, type and irrigation strategies), soil properties and rainfall. Typically, $\mathrm{S}$ is not expected to accumulate in soils, since it is easily leached, particularly during the wet season, when almost all $S$ applied is removed from soils (Hinckley and Matson, 2011). Therefore, though higher $S$ levels were observed in the oldest vineyard soils (Fig. 3), this is not probably related to accumulation processes but with a greater frequency in S applications on vines. Nevertheless, the particle size and formulation of the $S$ product may have some influence on the fate of this element (whereas fungicidal $\mathrm{S}$ consists of small particles with a large surface area favouring a rapid volatilization, the S-containing fertilizers are prepared to slow up S oxidation).

Soils from the studied areas are in general poor in organic carbon (OC) and $\mathrm{N}$ (Table 1). The behavior of OC and $\mathrm{N}$ are quite similar and below the background levels of the area, with the higher values found at the oldest vineyard, and the lower ones in the new vineyard (Fig. 3). The lower levels observed in the youngest vineyards are probably a result of tillage-based management of the soil surface, which limited the potential for organic matter (OM) accumulation.

The mean value of soil $\mathrm{C} / \mathrm{N}$ ratio is $11 \pm 2.36$ across the whole area (Table 1 ) and very similar between each vineyard (Fig. 3 ). This is in agreement with the values found for topsoil of arable land, which typically ranges from 10 to 12 (Osman, 2013), and increase in the subsoil. Also, identical $\mathrm{C} / \mathrm{N}$ values have been reported by other authors for tilled vineyards on sloping land, and under different soil and climate conditions (Stevanato et al., 2014). This indicates that runoff and the conventional tillage-based managements, which limit the input of fresh organic residues and enhance mineralization of existing soil OM, are probably the main factors contribution to the low $\mathrm{C} / \mathrm{N}$ ratios in these soils.

Phosphorus $(\mathrm{P})$ is a macronutrient for plants, with a great impact on agriculture production. The increasing application of $\mathrm{P}-$ fertilizers in the recent years has significantly improved soil $\mathrm{P}$ status in most regions of the world (Mejías et al., 2013; Rubaek et al., 2013), but has been caused P accumulation in some soils (Cordell et al., 2009; Maguire et al., 2009; Tóth et al., 2014; Wang et al., 2014). The accumulation of $P$ in soil also has negative consequences since: the accumulated fraction is an unnecessary cost to the farmer; phosphates are non-renewable resources; it may cause negative environmental impacts, because even small amounts of $P$ leaching into watercourses can cause eutrophication processes (Elser and Bennett, 2011).

In acidic soils, $\mathrm{P}$ can be predominantly adsorbed by $\mathrm{Al} / \mathrm{Fe}-$ oxyhydroxides (Parfitt, 1989). Furthermore, in such conditions, P become available at extremely slow rate, which may cause nutritional deficiencies for plants. Total $\left(\mathrm{P}_{\text {total }}\right)$ and available $\left(\mathrm{P}_{\text {avail }}\right) \mathrm{P}$ content in studied soils were higher than the background value (Fig. 3), and no significant correlation was found between both. The higher and lowest amounts of $\mathrm{P}_{\text {total }}$ were found in the vineyard with an age between 15 and 50 (Fig. 3), which is probably related with the type of P-fertilizers used and with the application rates as demonstrated by Kang et al. (2011).

\section{2. $\mathrm{Cu}$ in the vineyard soils}

The total $\mathrm{Cu}$ contents (18-211 $\mathrm{mg} \mathrm{kg}^{-1}$, Table 1 ) are high when compared with the mean level of $15.5 \mathrm{mg} \mathrm{kg}^{-1}$ for agricultural soils in Europe (Oorts, 2013). Also, these concentrations are high when compared with the background value of the area $\left(16 \mathrm{mg} \mathrm{Cu} \mathrm{kg}{ }^{-1}\right.$, Fig. 3). These data clearly demonstrate that the source of $\mathrm{Cu}$ in the studied vineyard soils is attributed to the application of $\mathrm{Cu}$-based fungicides, as the historical use of Bordeaux mixture $\left[\mathrm{CuSO}_{4}+\mathrm{Ca}(\mathrm{OH})_{2}\right]$. The Bordeaux mixture has been widely used since the end of 19th century in several countries (McBride, 1981; Romić et al., 2014), however the exact period time that this compound started to be used in the studied region is not known. Moreover, there is no available data about the number of applications and the amount of $\mathrm{Cu}$ applied.

Previous studies conducted in vineyard topsoils from other European countries reported $\mathrm{Cu}$ contents ranging from 14 to $945 \mathrm{mg} \mathrm{kg}^{-1}$ (Komárek et al., 2010), exceeding the limits of 50-140 mg kg-1, set by the EU Council Directive 86/278/EEC. Slightly lower values were reported in Australian vineyard soils, ranging between 6 and $249 \mathrm{mg} \mathrm{kg}^{-1}$, probably due to the lower average annual usage of $\mathrm{Cu}$-based fungicides, which is estimated to be $5-13 \mathrm{~kg} \mathrm{ha}^{-1}$, in contrast to the typical annual usage of $10-50 \mathrm{~kg} \mathrm{ha}^{-1}$ in some European regions (Wightwick et al., 2008). Levels as higher as $3200 \mathrm{mg} \mathrm{kg}^{-1}$ were found in Brazilian vineyard soils (Mirlean et al., 2007), whereas in the Champagne region (France) the maximum level of $\mathrm{Cu}$ found was $1500 \mathrm{mg} \mathrm{kg}{ }^{-1}$ (Besnard et al., 2001). Such high levels as the ones found in Brazil reflect the impact of the climate, since high volumes of fungicides are needed in areas with greater humidity and precipitation for diminishing downy mildew attacks (Komárek et al., 2010). For example, Deluisa et al. (1996) studied vineyards cultivated in distinct climatic conditions [humid (rainfall $>1200 \mathrm{~mm} \mathrm{y}^{-1}$ ), plain zone (rainfall: 800-1000 $\mathrm{mm} \mathrm{y}^{-1}$ ), and drier (rainfall: 400-800 $\mathrm{mm} \mathrm{y}^{-1}$ )] and found that the mean $\mathrm{Cu}$ levels gradually decreased from $297 \mathrm{mg} \mathrm{kg}^{-1}$, to $200 \mathrm{mg} \mathrm{kg}^{-1}$, and $75 \mathrm{mg} \mathrm{kg}^{-1}$ respectively. On the other hand, Wightwick et al. (2008) found no apparent link between Australian climatic regions and annual $\mathrm{Cu}$ usage, and suggested that individual vineyard management practices, rather than climate, influence the extent of $\mathrm{Cu}$ use in viticulture.

It is interesting to note that $\mathrm{Cu}$ contents of the surface soils varied widely, as shown in Table 2 . Such large variability could be 

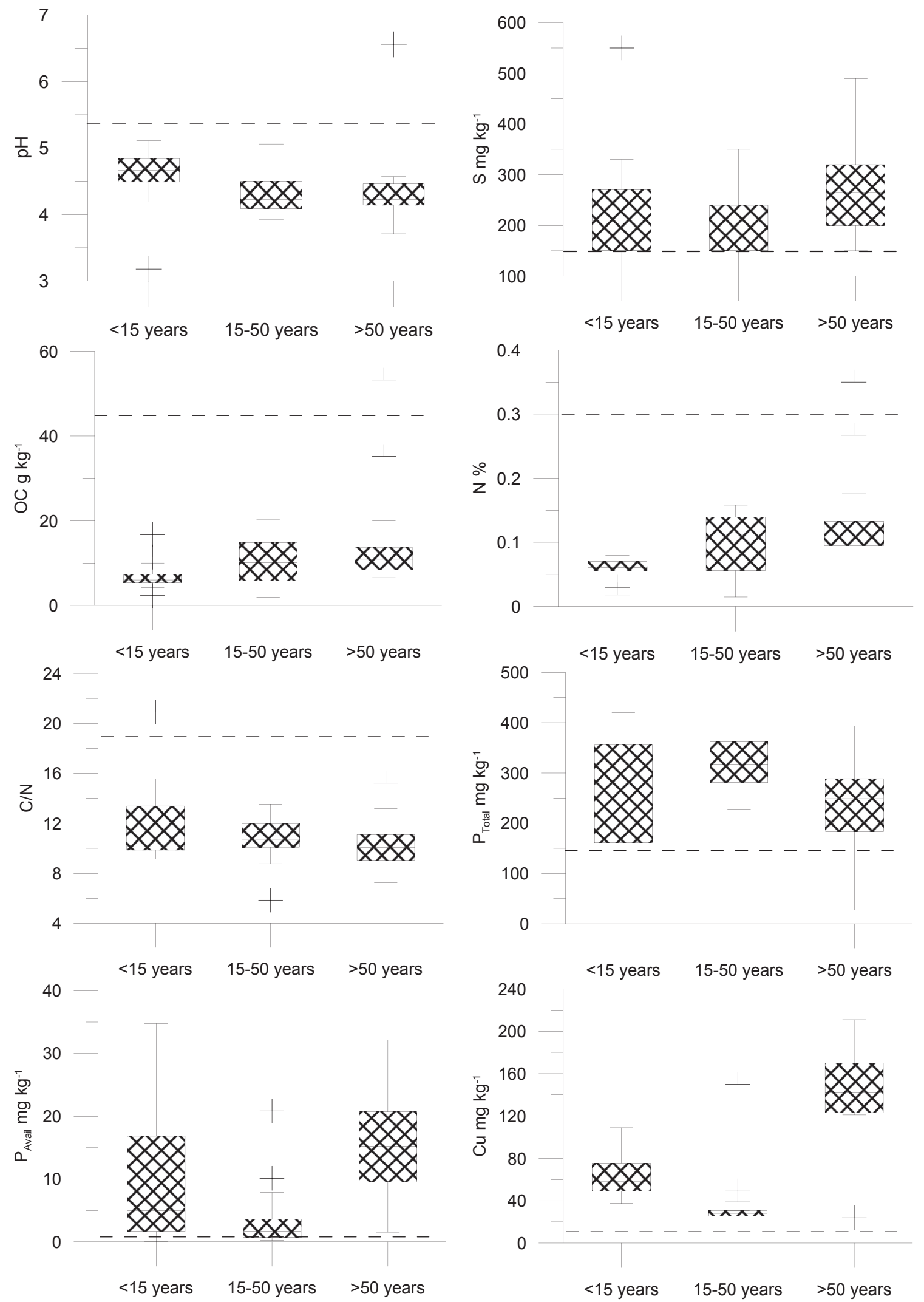

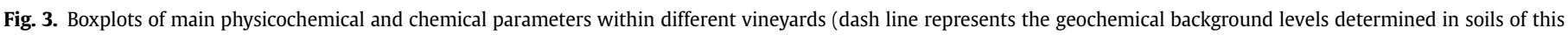
area). 

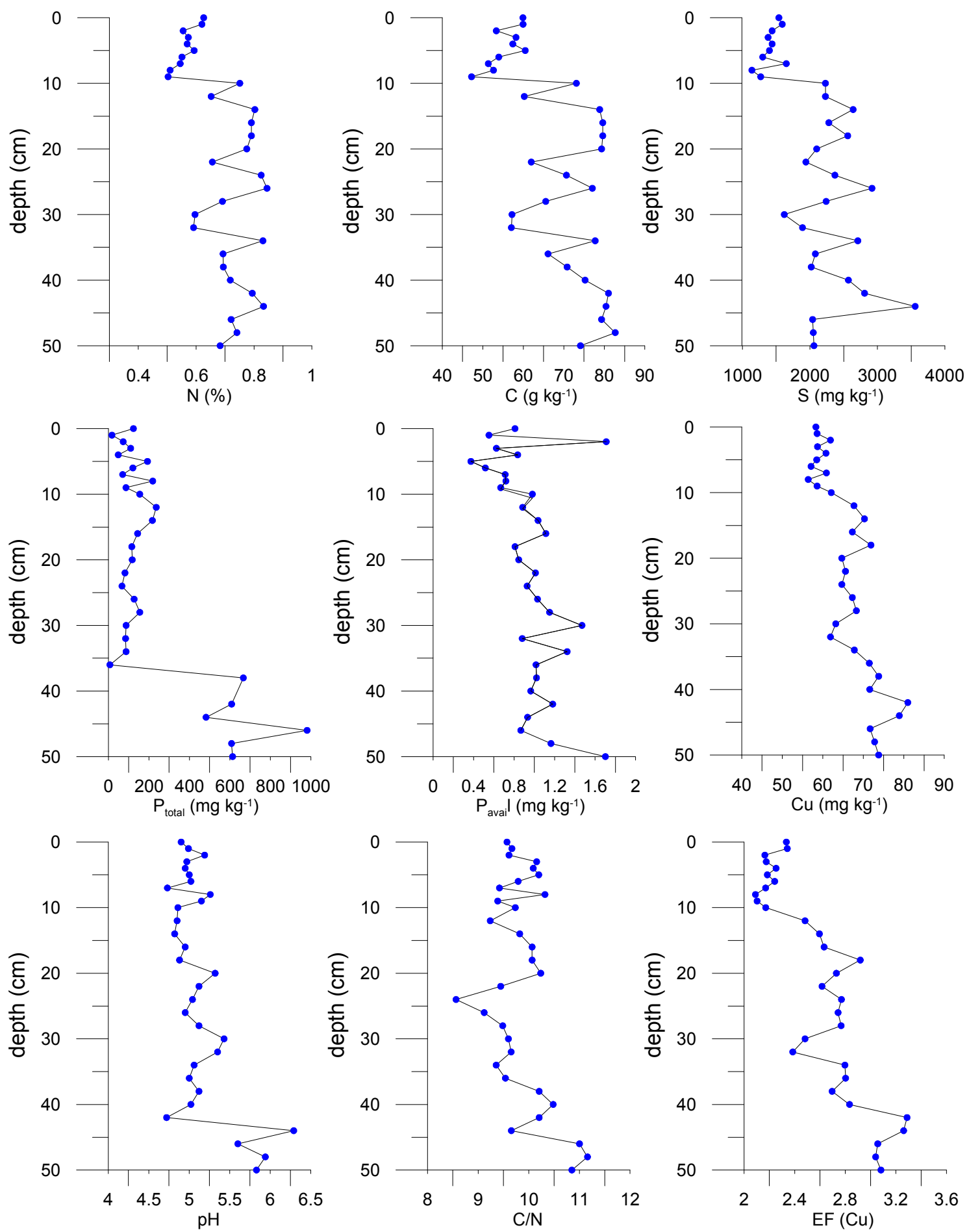

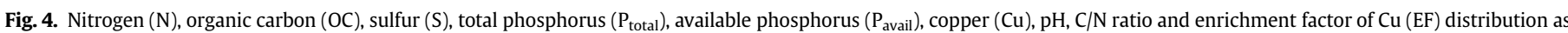
a function of sediment core depth.

attributed to the number of $\mathrm{Cu}$ applications. Moreover, $\mathrm{Cu}$ retention and, consequently, its accumulation in the surface soils within the same region could be influenced by several factors, such as: the soil's physicochemical parameters (e.g.: OC content, cation exchange capacity, and $\mathrm{pH}$ ); the local topography; the history of $\mathrm{Cu}-$ based fungicides applications; and different management practices (e.g.: tillage, OM incorporation) (Wightwick et al., 2008; Fernández-Calviño et al., 2009).
Previous studies demonstrated that prolonged periods of fungicide treatments result in a more pronounced $\mathrm{Cu}$ accumulation in soils (Romić et al., 2014; Rusjan et al., 2007). Nevertheless, other studies did not found a significant relationship between vineyard age and $\mathrm{Cu}$ accumulation (Wightwick et al., 2008). Data obtained for Douro region did not allow to establish a correlation between the amount of $\mathrm{Cu}$ in soils and the age of vineyards, despite the highest $\mathrm{Cu}$ contents were found at the oldest vineyard (mean 
Table 2

Spearman correlations between soil physicochemical and chemical properties.

\begin{tabular}{llllllll}
\hline & $\mathrm{N}$ & $\mathrm{C}$ & $\mathrm{pH}$ & $\mathrm{P}_{\text {total }}$ & $\mathrm{P}_{\text {avail }}$ & $\mathrm{S}$ & $\mathrm{Cu}$ \\
\hline $\mathrm{N}$ & 1.00 & $\mathbf{0 . 9 4}$ & $-\mathbf{0 . 6 1}$ & -0.01 & 0.41 & $\mathbf{0 . 5 1}$ & $\mathbf{0 . 4 0}$ \\
$\mathrm{C}$ & & 1.00 & $-\mathbf{0 . 5 2}$ & 0.02 & 0.28 & $\mathbf{0 . 4 4}$ & $\mathbf{0 . 3 2}$ \\
$\mathrm{pH}$ & & & 1.00 & 0.17 & -0.36 & $-\mathbf{0 . 5 0}$ & -0.18 \\
$\mathrm{P}_{\text {total }}$ & & & & 1.00 & -0.11 & -0.07 & -0.27 \\
$\mathrm{P}_{\text {avail }}$ & & & & & 1.00 & $\mathbf{0 . 4 0}$ & $\mathbf{0 . 6 8}$ \\
$\mathrm{S}$ & & & & & & 1.00 & $\mathbf{0 . 5 6}$ \\
$\mathrm{Cu}$ & & & & & & & 1.00 \\
\hline
\end{tabular}

Values in bold correspond to significant correlations to $\mathrm{p}<0.01$ level of significance

$144 \mathrm{mg} \mathrm{kg}^{-1}$ ). Although, the lowest $\mathrm{Cu}$ contents were found at the middle age vineyard (mean $35.4 \mathrm{mg} \mathrm{kg}^{-1}$ ). In addition, the lack of relationship between the age and the $\mathrm{Cu}$ content may also be related to management practices such as ploughing and/or remobilization of soils during the new vine plantation.

Considering the influence of soils properties on $\mathrm{Cu}$ contents, no strong correlations were found between the analyzed soil parameters and $\mathrm{Cu}$ levels (Table 2). The strongest correlations were found between $\mathrm{Cu}$ and $\mathrm{P}_{\mathrm{avail}}$ and with $\mathrm{S}$. The correlation between $\mathrm{Cu}$ and $\mathrm{P}_{\text {avail }}$ can be explain due to the fact that the application of P-fertilizer could also contribute to the accumulation of $\mathrm{Cu}$ in surface soil since $\mathrm{Cu}^{2+}$ can form an insoluble salt $\left(\mathrm{CuHPO}_{4}\right)$ with $\mathrm{HPO}_{4}^{2-}$ (Shuman, 1988).

\subsection{Levels of synthetic organic pesticides in vineyard soils}

Herbicides were detected only in one sample (located in the old vineyard) at levels below $8.5 \mu \mathrm{g} \mathrm{kg}{ }^{-1}$. Herbicides are normally applied in spring (February-May) and, due to their physicochemical properties (high polarity, low $\mathrm{K}_{\mathrm{OC}}$ values, and low half-live values), they do not tend to persist in soils for a long time, being easily leached to groundwater or to nearby aquatic systems. Thus, since sampling was performed at the end of summer, the results obtained are not surprising.

Regarding the five fungicides analyzed, folpet was not detected in any sample, and tebuconazole was detected in less than $50 \%$ of samples, whereas penconazole was detected in all samples (Table 3). Previous studies, found similar results for folpet once even during the application period this fungicide was not detected in soil samples due to its rapid degradation (Bermúdez-Couso et al., 2007; Schreck et al., 2008). Tebuconazole and penconazole have similar solubility in water (0.036 and $0.073 \mathrm{~g} \mathrm{~L}^{-1}$, respectively) and the same $\log \mathrm{K}_{\mathrm{OW}}$ value (3.7), but a different $\mathrm{K}_{\mathrm{OC}}$ (769 and $2205 \mathrm{~L} \mathrm{~kg}^{-1}$, respectively) and soil half-life (40-170 and 133-343 days, respectively). Thus, the higher frequency of detection of penconazole is likely to be related to its lower mobility and higher persistence.

Considering the median concentration of all samples, metalaxyl was the most abundant ( $22 \mu \mathrm{g} \mathrm{kg}^{-1}$ ), followed by boscalid
(9.6 $\left.\mu \mathrm{g} \mathrm{kg}^{-1}\right)$, and penconazole $\left(3.6 \mu \mathrm{g} \mathrm{kg}^{-1}\right)$. Metalaxyl has a short half-live (10-40 days), it is soluble $\left(8.4 \mathrm{~g} \mathrm{~L}^{-1}\right)$, and very mobile (log $\left.\mathrm{K}_{\mathrm{OW}}=1.8 ; \mathrm{K}_{\mathrm{OC}}=30-300 \mathrm{~L} \mathrm{~kg}^{-1}\right)$, thus, it is not expected to be retained in soils (Bermúdez-Couso et al., 2007; Komárek et al., 2010; Schreck et al., 2008). However, these higher levels observed for metalaxyl, as well as for boscalid, are probably related to their application period, since they are applied latter in the summer. Moreover, they are also the most commonly used in this area.

Levels of fungicides found in the vineyards at Douro region are low, but similar to that observed in other vineyard areas. For example, in the Rias Baixas vineyards (Spain) a survey, which included the analysis of metalaxyl, penconazole, and tebuconazole, was performed 1 and 9 months after the last application and only tebuconazole was detected ( $12 \mu \mathrm{g} \mathrm{kg}^{-1}$ in one sample, 1 month after the last application) (Rial-Otero et al., 2004). In the nearby region of Ourense, Bermúdez-Couso et al. (2007) found levels of metalaxyl and penconazole similar to the ones from the present study, with exception of samples collected during the application period, which showed levels higher than $100 \mu \mathrm{g} \mathrm{kg}^{-1}$. In vineyard soils form France, metalaxyl was found at levels of $50 \mu \mathrm{g} \mathrm{kg}^{-1}$, one day after application (Schreck et al., 2008). Therefore, the lower levels found in the studied area can be related to the sampling period ( 1 month after the last application). Moreover, this was a dry year (Fig. 1), resulting in low application rates of fungicides due to the low incidence of diseases.

With exception of metalaxyl, which shows higher levels in the older vineyard, for the other fungicides there is no trend between age of vines and levels of fungicides. Penconazole showed similar median values in the three areas, whereas median levels of boscalid and tebuconazol were similar in the two older vineyards, and they were not detected in the youngest one. Thus, differences in the levels of fungicides found in the three areas are more likely to be related with management practices (different timing and mode of application) than with its accumulation in soils caused by successive applications. Indeed, only boscalid showed a significant correlation with $\mathrm{OC}$, which is one of the most important properties regarding sorption of these compounds in soils (Komárek et al., 2010). Moreover, the high range of values observed in the oldest vineyard is related to a hotspot observed for metalaxyl, penconazol, and boscalid, which it is suspected to be related with the local of storage and preparation of pesticides.

Regarding insecticides currently applied, chlorpyriphos was not detected in any sample and deltamethrin was detected at very low levels. These results are in line with other studies, since insecticides are not commonly used in vines and they are applied only sporadically (Schreck et al., 2008). On the other hand, insecticides that were used in the past, but due to their persistence, lower mobility, and toxicity, monitorization of their levels in the environment is still need, only $\sum$ DDX showed significant levels. Endosulfan was detected at very low levels, and no differences were observed between the three areas, which may indicate that levels

Table 3

The frequency of detection (\%) and levels $\left(\mu \mathrm{g} \mathrm{kg}{ }^{-1}\right)$ of fungicides and insecticides detected in soils from the three studied vineyards.

\begin{tabular}{|c|c|c|c|c|c|c|c|c|c|}
\hline & \multicolumn{3}{|l|}{ V1 (<15 years) } & \multicolumn{3}{|c|}{ V2 (15-50 years) } & \multicolumn{3}{|l|}{ V3 (>50 years) } \\
\hline & Freq detection & range & median & Freq detection & range & median & Freq detection & range & median \\
\hline Metalaxyl & 40 & bdl-0.34 & - & 100 & $10-40$ & 22 & 100 & $25-70$ & 39 \\
\hline Penconazol & 100 & $2.9-34$ & 3.6 & 100 & $1.9-4.6$ & 3.5 & 100 & $2.6-127$ & 4.7 \\
\hline Tebuconazol & 0 & - & - & 60 & bdl-11 & 3.5 & 80 & bld-13 & 4.2 \\
\hline Boscalid & 0 & - & - & 100 & $3.8-84$ & 13 & 100 & $8.7-145$ & 11 \\
\hline Deltamethrin & 100 & $1.2-2.4$ & 2.0 & 40 & bdl-24 & - & 100 & $3.2-15$ & 7.5 \\
\hline Endosulfan & 80 & bdl-2.6 & 1.4 & 80 & bdl-3.4 & 1.5 & 100 & $0.6-3.1$ & 1.3 \\
\hline$\sum D D X$ & 100 & $0.24-5.8$ & 1.0 & 20 & bdl-0.31 & - & 100 & $11-40$ & 24 \\
\hline
\end{tabular}

bdl - bellow detection limit. 
are related with global background contamination. DDX, banned in Portugal in 1988, showed very high values in vineyards with more than 50 years. Indeed, the pattern of the DDX mixture is dominated by the metabolite 4,4-DDE, ranging from 53 to $100 \%$, which indicates that it is a legacy of the past (Neitsch et al., 2016). Levels of DDTx found in the studied area are slightly lower than the typical residual levels found in southwestern Germany (20-60 $\mu \mathrm{g} \mathrm{kg}^{-1}$ ), where this pesticide was banned 40 years ago (Neitsch et al., 2016). However, these values are similar to the ones found in vineyard soils from the Ebro River basin, in north-eastern Spain $\left(27.8 \mu \mathrm{g} \mathrm{kg}^{-1}\right.$ for 4,4-DDE), where this pesticide was banned in 1977 (Hildebrandt et al., 2009). On the other hand, these values can be considered high when comparing with the ones found in vineyards from another agricultural region in Spain (range of $0.08-0.62 \mu \mathrm{g} \mathrm{kg}^{-1}$, median of $0.60 \mu \mathrm{g} \mathrm{kg}^{-1}$ ) (Muñoz-Arnanz and Jiménez, 2011). Considering some of the existing guideline values for soil quality (e.g. Dutch, USEPA), the area corresponding to the older vineyard can be considered contaminated with DDX, and thus, the potential risks to the environment should be assessed. Moreover, the effect of modern pesticide, which typically contain high levels of surfactants, on the mobilization of DDX should be assessed (Neitsch et al., 2016).

As observed for $\mathrm{Cu}$ and for the more persistent compounds such as deltamethrin (Table 3), the higher levels of the $\sum$ DDX were observed in the in old vineyard, followed by the youngest one and the less contaminated was the medium age vineyard. Indeed, there is a significant relationship between DDX and $\mathrm{Cu}$ levels $\left(r^{2}=0.7198\right)$. The higher levels of contaminants found in the older vineyard reflect the accumulation and persistence of some pesticides used in the treatment of vines over time. The higher levels found in the youngest vineyard compared with the one with intermediate age are probably related with management practices such as ploughing, reflecting the importance of such practices in the mobilization of contaminants.

\subsection{Distribution of physicochemical parameters in sediment core samples}

The sediment column that was deposited over the years in dam reservoirs are an important record of the geogenic sources, as well as of the human activities exerted on environment. Despite the relevant information that these sediments contain, they are not widely studied, comparing with natural lakes, probably due to the complex sedimentation patterns caused by changes in water levels and in the discharges of input streams, in a relatively short period of time (Shotbolt et al., 2005; Tibb et al., 2010).

Favoring by the proximity of vineyards to the Varosa dam and by their slope, the sediments that were and are being deposited in the Varosa Reservoir certainly have a significant contribution from vineyard soils. Thus, in order to understand the contribution of vineyard soils to the sedimentation rate, but especially the changes

\section{Table 4}

Spearman's correlation coefficient between physicochemical and chemical parameters in sediment core samples.

\begin{tabular}{llllllll}
\hline & $\mathrm{pH}$ & $\mathrm{N}$ & $\mathrm{C}$ & $\mathrm{S}$ & $\mathrm{P}_{\text {total }}$ & $\mathrm{P}_{\text {avail }}$ & $\mathrm{Cu}$ \\
\hline $\mathrm{pH}$ & 1.00 & -0.08 & 0.01 & -0.18 & 0.16 & 0.21 & 0.13 \\
$\mathrm{~N}$ & & 1.00 & $\mathbf{0 . 9 0}$ & $\mathbf{0 . 9 2}$ & 0.29 & 0.48 & $\mathbf{0 . 6 0}$ \\
$\mathrm{C}$ & & & 1.00 & $\mathbf{0 . 8 0}$ & 0.45 & 0.43 & $\mathbf{0 . 7 5}$ \\
$\mathrm{S}$ & & & & 1.00 & 0.20 & $\mathbf{0 . 5 3}$ & $\mathbf{0 . 6 8}$ \\
$\mathrm{P}_{\text {total }}$ & & & & & 1.00 & 0.22 & $\mathbf{0 . 4 6}$ \\
$\mathrm{P}_{\text {avail }}$ & & & & & & 1.00 & $\mathbf{0 . 6 1}$ \\
$\mathrm{Cu}$ & & & & & & & 1.00 \\
\hline
\end{tabular}

Values in bold correspond to significant correlations to $\mathrm{p}<0.01$ level of significance. operating along the years in the agriculture management in this region, element fluctuation in the core sediments was studied.

Fig. 4 shows the vertical distributions of some chemical and physicochemical parameters $\left(\mathrm{N}, \mathrm{OC}, \mathrm{S}, \mathrm{P}_{\text {total }}, \mathrm{P}_{\text {avail }}, \mathrm{Cu}, \mathrm{pH}, \mathrm{C} / \mathrm{N}\right)$ in the sediment core samples, as well as the EF for $\mathrm{Cu}$. The N, OC and $\mathrm{S}$ concentrations range between 0.50 and $0.85 \%$ (mean of $0.68 \% \pm 0.11$ ), $47.2-82.7 \mathrm{~g} \mathrm{~kg}^{-1}$ (mean of $67.2 \pm 10.9 \mathrm{~g} \mathrm{~kg}^{-1}$ ) and $1140-3560 \mathrm{mg} \mathrm{kg}^{-1}$ (mean of $2034 \pm 567.2 \mathrm{mg} \mathrm{kg}^{-1}$ ), respectively. In general, levels are lower in the first $10 \mathrm{~cm}$, with a tendency to increase with depth. Also, these three parameters show similar trends with depth, which are reinforced by the significant positive correlations between them (Table 4), suggesting a common origin. When comparing these values with that one's determined in soils is possible to verified the big differences between both compartments, where the higher levels in sediments reflect the accumulation of these macronutrients coming from upstream draining basin, which preservation are favoured due to prevailing reduction conditions below the water column.

The first $20 \mathrm{~cm}$ of core sediments profile do not reveal major shifts in $\mathrm{C} / \mathrm{N}$ ratios, suggesting a rather constant OM source. In addition, these values are close to the mean value found in vineyard soils, which may indicate a direct contribution from the soils of this area. At deeper layers, the $\mathrm{C} / \mathrm{N}$ values are slightly higher compared to the upper sediments, where major shifts were observed (Fig. 4). A significant decrease occurs between 20 and $25 \mathrm{~cm}$, followed by an increase tendency with depth. Higher values may reflect preferential the preservation of $\mathrm{OM}$ due reduction conditions and/or increased contribution of terrestrial OM (Mügler et al., 2010).

The $P_{\text {total }}$ concentration vary along profile (Fig. 4), showing higher concentrations in the deeper layers, most probably due to excessive nutrients (e.g. N-P-K type) input from agriculture in the past. The $\mathrm{P}_{\text {total }}$ distribution shows a similar pattern with $\mathrm{pH}$, indicating that the increase of $\mathrm{pH}$ may also promote the immobilization of $\mathrm{P}$ in sediments (Fig. 4). The $\mathrm{P}_{\text {avail }}$ concentrations are very low, more or less constant along the profile (Fig. 4), and, in general, lower than the levels in vineyard soils, which may indicate that $P_{\text {avail }}$ is readily uptake by vines.

The EF of $\mathrm{Cu}$ is greater than 1 in all core sections (Fig. 4), confirming the inputs of $\mathrm{Cu}$ into the Varosa Reservoir, with an anthropogenic origin (vine practices). Anyway, Cu content is slight higher in soils. Similar to $\mathrm{P}_{\text {total }}$, the EF of $\mathrm{Cu}$ shows an increase in deeper layers, reflecting that in past the use of agrochemicals was more pronounced than nowadays (Fig. 4). Nevertheless, the highest values of this index were observed between 10 and $28 \mathrm{~cm}$ and in bottom part of the core $(40-45 \mathrm{~cm})$. This is probable related with more intense precipitation periods that, in addition to favour leaching processes, also conducts to more intense applications of Cu-based pesticides (e.g. Bordeaux mixture).

In order to date the geochemical historical records in sediments and associate this with major climatic events or major anthropogenic actions in the region, $\mathrm{a}^{210} \mathrm{~Pb}$ geochronological dating was attempted. Unfortunately, the results obtained were not consistent and did not allow to establish a precise chronology of the sediments. Thus, to complement the lack of core dating, Principal Component Analysis (PCA) was performed. The data set used for PCA contained 8 variables and 31 sediment samples. The first two factors accounting $71.3 \%$ of total variance (Fig. 5a), were retained. Factor 1 accounts for $55.1 \%$ of the total variance and includes N, OC, $\mathrm{S}, \mathrm{P}_{\text {total }}, \mathrm{P}_{\text {avail }}$ and $\mathrm{Cu}$ on opposition to Al. Enrichments in N, OC, S, $\mathrm{P}_{\text {total }}, \mathrm{P}_{\text {avail }}$ and $\mathrm{Cu}$ are commonly derived from agriculture activities, whereas in these environments $\mathrm{Al}$ are mainly related to geogenic sources. The $\mathrm{pH}$, included in factor 2 , accounts for $19.1 \%$ of the total variance.

Over time, sediments that were deposited in the dam are characterized by a high variability (Fig. 5b). For both factors the 
a)
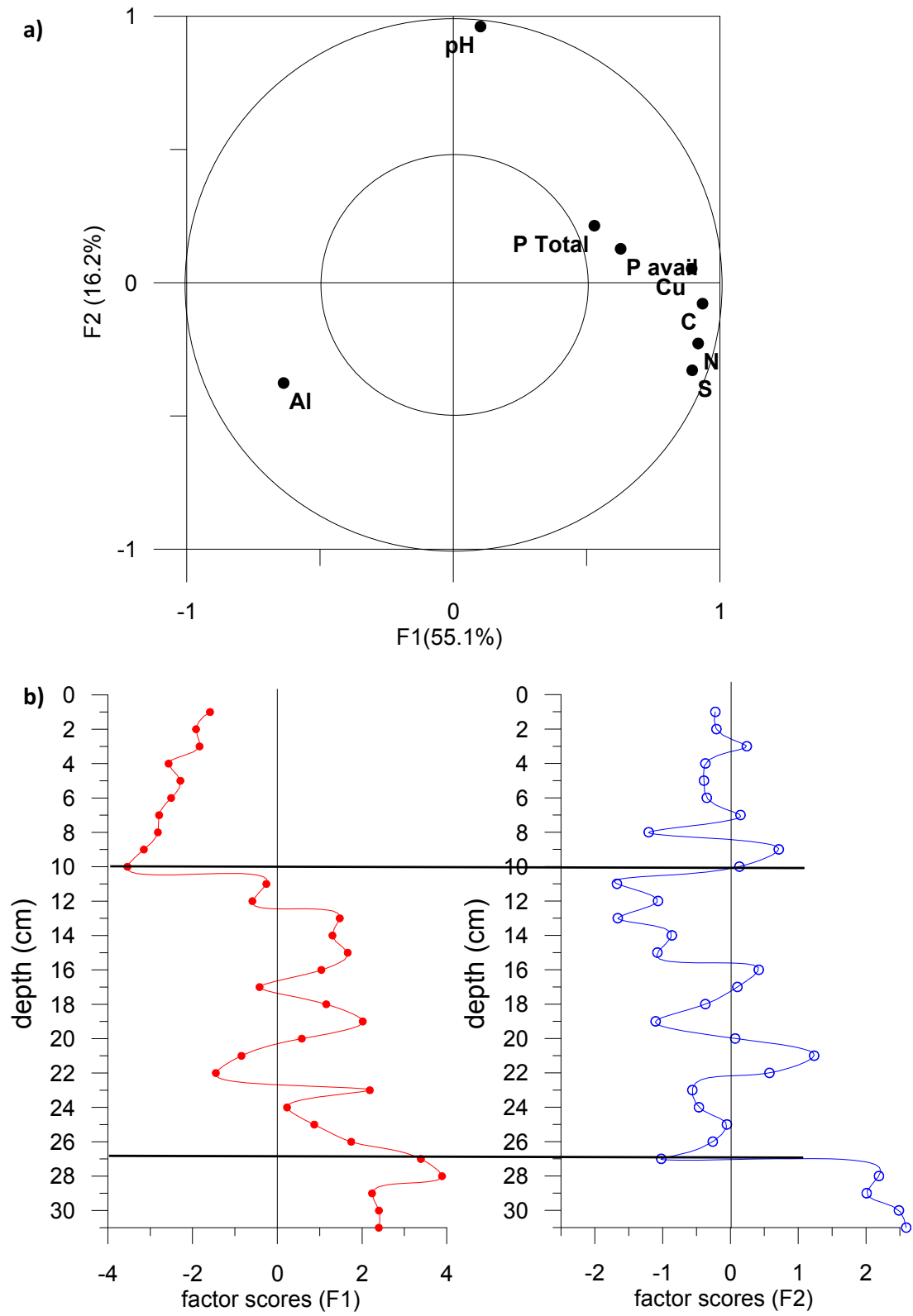

Fig. 5. Representation of the first two PCA factorial plans (F1 vs F2) according to variables association (a), and their variation over core profile (b).

most significant changes occur at $10 \mathrm{~cm}$ and at $27 \mathrm{~cm}$. In the first $10 \mathrm{~cm}$, the geogenic component is dominant in relation to the agriculture contribution. Below this depth, the contribution of agriculture practices is more evident, despite some sporadic episodes of greater geogenic contribution (Fig. 5b). The influence of $\mathrm{pH}$ in first $10 \mathrm{~cm}$ does not seem to be important, whereas between 10 and $27 \mathrm{~cm}$ it seems that there is a relationship between $\mathrm{pH}$ and agricultural contribution. Thus, in layers where the agriculture contribution is higher, the $\mathrm{pH}$ values are lower and on the other hand, the geogenic contribution is higher when the $\mathrm{pH}$ increases.

At large temporal scale, the high $\mathrm{C}-\mathrm{N}-\mathrm{S}-\mathrm{Cu}-\mathrm{P}_{\text {total }}$ and $\mathrm{P}_{\text {avail }}$ contents could result of the more intensive rain periods (Fig. 1), where application of pesticides is more intensified and the erosion processes favoured. Moreover, the loss of nutrients and other elements from the soil and their deposition on dam reservoir can be directly influenced by rainfall intensity and time. Thus, the close links between $\mathrm{Cu}$ and organic fractions ( $\mathrm{C}, \mathrm{N}$ and $\mathrm{S}$ ) and $\mathrm{P}$ of the sediments suggest a similar source. However, the punctual enrichment of $\mathrm{Cu}$ and $\mathrm{P}$ may also be associated with small erosion events (Quinton et al., 2001; Quinton and Catt, 2007). This is due to the wide range of particle sizes mobilized during intense rainy events, whereas in the lower intensity events the mobilization of fine particles is favoured, in which metals are preferably sorbed (Quinton and Catt, 2007). Likewise, the OC enrichment ratios are greater for sediments displaced by low intensity rainfall storms (Jacinthe et al., 2004; Martínez-Mena et al., 2012). In addition, as previously referred, soil erosion can also be accelerated by land use and management practices, such as tillage and intensive use of post-emergence herbicides (Poeplau and Don, 2013; Beniston et al., 2015; Labrière et al., 2015). 


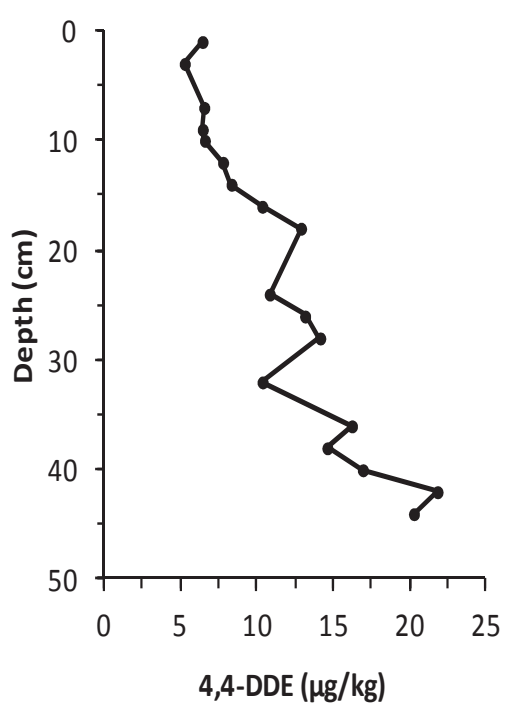

Fig. 6. 4,4-DDE distribution as a function of sediment core depth.

\subsection{Levels of synthetic organic pesticides in sediment core}

Regarding the profile of $\sum D D X$ in the sediment core, and similar to soils, 4,4-DDE was the most frequently detected compound in these samples, which is in line with other studies (Thevenon et al., 2013; Bettinetti et al., 2016; Liao et al., 2017). Since 4,4-DDE is an aerobic degradation product of DDT, it means that DDT was probably degraded in soils and then remobilized into the aquatic system (Sabatier et al., 2014). Indeed, the relatively high levels found in the upper layers (around $6.5 \mu \mathrm{g} \mathrm{kg}^{-1}$ ), suggest that there is still an input. Nevertheless, the observed increase in the concentrations of 4,4-DDE levels with depth (Fig. 6), reflects the legacy of the past, and the behavior is similar to $\mathrm{Cu}$. In fact, there is a significant correlation between these two contaminants $\left(r^{2}=0.70\right)$. Several studies indicate that DDX residues in the sediment cores reached peak values in the late 1970 s or early 1980 s, which was the period of maximum use around the world and coincides with the age of the dam. The decrease in levels between 2 and $10 \mathrm{~cm}$, should reflect the prohibition of this pesticide that occurred in 1988. However, other management practices can explain the continuous input of this contaminant. For example, the increase in the use of postemergence herbicides, and the surfactants present in new pesticides formulations, have been related with remobilization of DDX (Neitsch et al., 2016; Sabatier et al., 2014). In recent years it is a common practice in Douro region the non-tillage practices, together with the application of herbicides only nearby the vine roots. Thus, these practices may result in a reduction of erosion, which can explain the more or less constant levels found in the first $10 \mathrm{~cm}$, as observed in the PCA analysis (Fig. 5 b).

The median concentration observed for 4,4-DDE was $10.6 \mu \mathrm{g} \mathrm{kg}^{-1}$, ranging between 5.25 and $21.8 \mu \mathrm{g} \mathrm{kg}^{-1}$, which can be considered low when comparing with hotspots such as the Palos Verdes Shelf (levels of 4,4-DDE as high as $25100 \mu \mathrm{g} \mathrm{kg}^{-1}$ in surface sediments and $28400 \mu \mathrm{g} \mathrm{kg}^{-1}$ in a sediment core; Liao et al., 2017). In Como Lake (Italy), concentrations of 4,4-DDE in sediment cores ranged from 27 to $75 \mu \mathrm{g} \mathrm{kg}^{-1}$, and no significant decrease over time (since DDT was banned until to 2016) was observed (Bettinetti et al., 2016). However, levels found in Douro's sediment core can be considered high when comparing with levels found in Tagus estuary (Portugal). In Tagus estuary the most contaminated core showed a range of values between 1.4 and $250 \mu \mathrm{g} \mathrm{kg}^{-1}$, but despite the very high maximum value, the median concentration was just
$4.6 \mu \mathrm{g} \mathrm{kg}^{-1}$ (Mil-Homens et al., 2016). Similarly, in Lake Brêt (Switzerland), concentrations of 4,4-DDE ranged from non-detect to $2.5 \mu \mathrm{g} \mathrm{kg}^{-1}$ (Thevenon et al., 2013). Nevertheless, according the Norwegian guidelines, based on ecotoxicological effects, the studied sediments can be classified as good, since most of values are between 0.5 and $20 \mu \mathrm{g} \mathrm{kg}^{-1}$. The upper limit for this class is based on the predicted no effect concentrations for chronic exposures to that compound (Bakke et al., 2010; Liao et al., 2017).

\section{Conclusions}

The vineyard soils of the studied area are, in general, acid, poor in macronutrients, and OM. In addition, a high variability of the contaminants studied was found between and in each vineyard. Residues of several pesticides (organic and inorganic) related to agricultural activities were found in soils. The levels found were in general low, with older vineyards showing higher levels of $\mathrm{Cu}$ and banned insecticides (such as DDT and its metabolites), evidencing the effects of accumulation and persistence of those pesticides. In addition to the physicochemical properties of pesticides, the period and rate of application, which highly depend on climacteric conditions, have a great impact on the amounts of pesticides presented in the soils. Thus, the results obtained depend on the sampling period.

The landscape morphology (characterized by steep slopes) of this area promotes soil erosion and migration of pollutants. Therefore, the study of sediment core of dam reservoir proved to be a useful tool to understand the legacy of contaminants input from soils. The increase of pesticides levels with depth reflect the intensive use of these substances in the past. Although, the variability observed at small scale shows different input events, i.e. geogenic versus anthropogenic contributions. In addition, the presence of the metabolite 4,4-DDE in the upper sediment layers indicate that soils are still a source of contamination. This suggests the importance of management practices (e.g. ploughing) in the soil erosion and in the mobilization of such contaminants to other environmental compartments.

\section{Acknowledgements}

This work was supported by FCT, through an individual research grant attributed to A. Cachada (SFRH/BPD/100429/2014) and N. Durães (SFRH/BPD/81059/2011), and through the research project DVINE (PTDC/CTE-GIX/112821/2009). This work was also supported by the Strategic Funding UID/GEO/04035/2013 (GEOBIOTEC), UID/Multi/04423/2013 (CIIMAR) and UID/AMB/50017/ 2013 (CESAM RU) through national funds provided by FCT and European Regional Development Fund (ERDF), in the framework of the PT2020 Partnership Agreement.

\section{References}

Adriano, D.C., 2001. Trace Elements in Terrestrial Environment; Biogeochemistry, Bioavailability and Risks of Metals. Springer, New York, p. 866.

Andersen, T., Aguiar, F.B., Curado, M.J., 2004. The Alto Douro Wine Region Greenway Landscape and Urban Planning, vol. 68, pp. 289-303.

Bakke, T., Källqvist, T., Ruus, A., Breedveld, G.D., Hylland, K., 2010. Development of sediment quality criteria in Norway. J. Soils Sediments 10, 172-178.

Beniston, J.W., Shipitalo, M.J., Lal, R., Dayton, E.A., Hopkins, D.W., Jones, F., Dungait, J.A.J., 2015. Carbon and macronutrient losses during accelerated erosion under different tillage and residue management. Eur. J. Soil Sci. 66 (1), 218-225. http://dx.doi.org/10.1111/ejss.12205.

Bermúdez-Couso, A., Arias-Estévez, M., Nóvoa-Muñoz, J.C., López-Periago, E., SotoGonzález, B., Simal-Gándara, J., 2007. Seasonal distributions of fungicides in soils and sediments of a small river basin partially devoted to vineyards. Water Res. 41, 4515-4525.

Besnard, E., Chenu, C., Robert, M., 2001. Influence of organic amendments on copper distribution among particle-size and density fractions in Champagne vineyard soils. Environ. Pollut. 112, 329-337. 
Bettinetti, R., Quadroni, S., Boggio, E., Galassi, S., 2016. Recent DDT and PCB contamination in the sediment and biota of the Como Bay (Lake Como, Italy) Sci. Total Environ. 542, 404-410. http://dx.doi.org/10.1016/ j.scitotenv.2015.10.099.

Bisson, L.F., Waterhouse, A.L., Ebeler, S.E., Walker, M.A., Lapsley, J.T., 2002. The present and future of the international wine industry. Nature 418, 696-699.

Boudesocque, S., Guillon, E., Aplincourt, M., Marceau, E., Stievano, L., 2007. Sorption of $\mathrm{Cu}(\mathrm{II})$ onto vineyard soils: macroscopic and spectroscopic investigations. J. Colloid Interface Sci. 307 (1), 40-49.

Bradl, H.B., 2004. Adsorption of heavy metal ions on soils and soils constituents. J. Colloid Interface Sci. 277 (1), 1-18.

Bundschuh, M., Goedkoop, W., Kreuger, J., 2014. Evaluation of pesticide monitoring strategies in agricultural streams based on the toxic-unit concept - experiences from long-term measurements. Sci. Total Environ. 484, 84-91.

Caetano, A.L., Goncalves, F., Sousa, J.P., Cachada, A., Pereira, E., Duarte, A.C., et al. 2012. Characterization and validation of a Portuguese natural reference soil to be used as substrate for ecotoxicological purposes. J. Environ. Monit. 14, 925-936.

Celardin, F., Trouillet, C., Tisiot, R., 2004. pH dependence of copper adsorption in vineyard soils of Geneva. Environ. Chem. Lett. 1, 225-227.

Cordell, D., Drangert, J., White, S., 2009. The story of phosphorus: global food security and food for thought. Glob. Environ. Change 19, 292-305.

Deluisa, A., Giandon, P., Aichner, M., Bortolami, P., Bruna, L., Lupetti, A., Nardelli, F. Stringari, G., 1996. Copper pollution in Italian vineyard soils. Commun. Soil Sci. Plant Analysis 27 (5-8), 1537-1548.

Elser, J., Bennett, E., 2011. Phosphorus cycle: a broken biogeochemical cycle. Nature 478 (7367), 29-31. http://dx.doi.org/10.1038/478029a.

European Commission, 2006. Regulation (EC) No 1907/2006 of the European Parliament and of the Council of 18 December 2006 Concerning the Registration, Evaluation, Authorisation and Restriction of Chemicals (REACH), Establishing a European Chemicals Agency, Amending Directive 1999/45/EC and Repealing Council Regulation (EEC) No 793/93 and Commission Regulation (EC) No 1488/94 as Well as Council Directive 76/769/EEC and Commission Directives 91/155/EEC, 93/67/EEC, 93/105/EC and 2000/21/EC. Official Journal of the European Union, L 396/1 of 30.12.2006, vol. 49. Office for Official Publications of the European Communities (OPOCE), Luxembourg.

FAO-UNESCO, 1974. Soil Map of the World. Vol. I - legend. Paris, p. 59.

Fernández-Calviño, D., Nóvoa-Muñoz, J.C., Díaz-Raviña, M., Arias-Estévez, M., 2009 Copper accumulation and fractionation in vineyard soils from temperate humid zone (NW Iberian Peninsula). Geoderma 153 (1-2), 119-129.

Franco-Uria, A., Lopez-Mateo, C., Roca, E., Fernandez-Marcos, M.L., 2009. Source identification of heavy metals in pastureland by multivariate analysis in NW Spain. J. Hazard. Mat. 165, 1008-1015.

Gavrilescu, M., 2005. Fate of pesticides in the environment and its bioremediation. Eng. Life Sci. 5, 497-526.

Gaw, S.K., Wilkins, A.L., Kim, N.D., Palmer, G.T., Robinson, P., 2006. Trace element and Sigma DDT concentrations in horticultural soils from the Tasman, Waikato and Auckland regions of New Zealand. Sci. Total Environ. 355 (1-3), 31-47.

Gonçalves, C., Alpendurada, M.F., 2005. Assessment of pesticide contamination in soil samples from an intensive horticulture area, using ultrasonic extraction and gas chromatography-mass spectrometry. Talanta 65, 1179-1189.

Griffith, C.M., Woodrow, J.E., Seiber, J.N., 2015. Environmental behavior and analysis of agricultural sulfur. Pest Manag. Sci. 71, 1486-1496.

Hildebrandt, A., Guillamón, M., Lacorte, S., Tauler, R., Barceló, D., 2008. Impact of pesticides used in agriculture and vineyards to surface and groundwater quality (North Spain). Water Res. 42, 3315-3326.

Hildebrandt, A., Lacorte, S., Barceló, D., 2009. Occurrence and fate of organochlorinated pesticides and $\mathrm{PAH}$ in agricultural soils from the Ebro River basin. Archives Environ. Contam. Toxicol. 57, 247-255.

Hinckley, E.-L.S., Matson, P.A., 2011. Transformations, transport, and potential unintended consequences of high sulfur inputs to Napa Valley vineyards. Proc Natl. Acad. Sci. U. S. A. 108 (34), 14 005-014 010.

Hinckley, E.L.S., Fendorf, S., Matson, P., 2011. Short-term fates of high sulfur inputs in Northern California vineyard soils. Nutr. Cycl. Agroecosyst 89 (1), 135-142.

Islam, M.S., Ahmed, M.K., Raknuzzaman, M., Habibullah-Al-Mamun, M., Islam, M.K., 2015. Heavy metal pollution in surface water and sediment: a preliminary assessment of an urban river in a developing country. Ecol. Indic. 48, 282-291.

Jacinthe, P.A., Lal, R., Owens, L.B., Hothem, D.L., 2004. Transport of labile carbon in runoff as affected by land use and rainfall characteristics. Soil Tillage Res. 77 (2), 111-123. http://dx.doi.org/10.1016/j.still.2003.11.004.

Kang, J., Amoozegar, A., Hesterberg, D., Osmond, L.D., 2011. Phosphorus leaching in a sandy soil affected by organic and inorganic fertilizer sources. Geoderma 161 (3-4), 194-201.

Klikocka, H., Kobiałka, A., Juszczak, D., Głowacka, A., 2015. The influence of sulphur on phosphorus and potassium content in potato tubers (Solanum tuberosum L.). J. Elem. 20 (3), 621-629. http://dx.doi.org/10.5601/jelem.2014.19.2.661.

Komárek, M., Čadková, E., Chrastný, V., Bordas, F., Bollinger, J.-C., 2010. Contamination of vineyard soils with fungicides: a review of environmental and toxicological aspects. Environ. Int. 36, 138-151.

Labrière, N., Locatelli, B., Laumonier, Y., Freycon, V., Bernoux, M., 2015. Soil erosion in the humid tropics: a systematic quantitative review. Agric. Ecosyst. Environ. 203 (0), 127-139. http://dx.doi.org/10.1016/j.agee.2015.01.027.

Larson, S.J., Capel, P.D., Majewski, M.S., 1997. Pesticides in surface waters distribution, trends, and governing factors. In: Gilliom, R.J. (Ed.), Series of Pesticides in Hydrologic System, 3. Ann Arbor Press, Chelsea, Michigan.
Liao, C., Taylor, A.R., Kenney, W.F., Schlenk, D., Gan, J., 2017. Historical record and fluxes of DDTs at the Palos Verdes Shelf superfund site, California. Sci. Total Environ. 581-582, 697-704.

Loska, K., Danuta, W., 2003. Application of principal component analysis for the estimation of source of heavy metal contamination in surface sediments from the Rybnik Reservoir. Chemosphere 51, 723-733.

Maguire, R.O., Rubæk, G.H., Haggard, B.E., Foy, B.H., 2009. Critical evaluation of the implementation of mitigation options for phosphorus from field to catchment scales. J. Environ. Qual. 38, 1989-1997. http://dx.doi.org/10.2134/jeq2007.0659 PMID: 19704142.

Martinez-Mena, M., Lopez, J., Almagro, M., Albaladejo, J., Castillo, V., et al., 2012. Organic carbon enrichment in sediments: effects of rainfall characteristics under different land uses in a Mediterranean area. Catena 94, 36-42.

McBride, M.B., 1981. Forms and distribution of copper in solid and solution phases in soil. In: Lonergan, J.F., Robson, A.D., Graham, R.D. (Eds.), Copper in Soils and Plants: Proceedings of the Golden Jubilee International Symposium, 7 - 9 May 1981. Academic Press Australi, Perth, Western Australia, pp. 25-45.

Mejías, J.H., Alfaro, M., Harsh, J., 2013. Approaching environmental phosphorus limits on a volcanic soil of Southern Chile. Geoderma 207, 49-57.

Meneses, B.M., Vale, M.V., Rei, R., 2014. A caraterização do uso e ocupação do solo de Portugal Uso e Ocupação do Solo em Portugal Continental in Avaliação e Cenários Futuros, Continental. Publisher: DGT, Editors: DGT, pp. 9-13. pp.

Mil-Homens, M., Vicente, M., Grimalt, J.O., Micaelo, C., Abrantes, F., 2016. Reconstruction of organochlorine compound inputs in the Tagus Prodelta. Sci. Total Environ. 540, 231-240.

Mirlean, N., Roisenberg, A., Chies, J.O., 2007. Metal contamination of vineyard soils in wet subtropics (southern Brazil). Environ. Pollut. 149 (1), 10-17.

Mügler, I., Gleixner, G., Günther, F., Mäusbacher, R., Daut, G., Schütt, B., Schwab, F., Schwark, L., Xu, B., Yao, T., Zhu, L., Yi, C., 2010. A multi-proxy approach to reconstruct hydrological changes and Holocene climate development of Nam Co, Central Tibet. J. Paleolimnol. 43, 625-648.

Muñoz-Arnanz, J., Jiménez, B., 2011. New DDT inputs after 30 years of prohibition in Spain. A case study in agricultural soils from south-western Spain. Environ. Pollut 159, 3640-3646.

Murphy, J., Riley, J.R., 1962. A modified single solution method for the determination of phosphorus in natural waters. An. Chem. Acta 27, 31-36.

Neitsch, J., Schwack, W., Weller, P., 2016. How do modern pesticide treatments influence the mobility of old incurred DDT contaminations in agricultural soils? J. Agric. Food Chem. 64, 7445-7451.

Nóvoa-Muñoz, J.C., Queijeiro, J.M.G., Blanco-Ward, D., Álvarez-Olleros, C., MartínezCortizas, A., García-Rodeja, E., 2007. Total copper content and its distribution in acid vineyards soils developed from granitic rocks. Sci. Total Environ. 378, 23-27.

Oorts, K., 2013. Copper. In: Alloway, J.B. (Ed.), Heavy Metals in Soils: Trace Metals and Metalloids in Soils and Their Bioavailability. Springer, Netherlands, Dordrecht, pp. 367-394.

Osman, K.T., 2013. Soils: Principles, Properties and Management. Springer, Dordrecht, p. 274.

Parat, C., Chaussod, R., Lévêque, J., Dousset, S., Andreux, F., 2002. The relationship between copper accumulated in vineyard calcareous soils and soil organic matter and iron. Eur. J. Soil Sci. 53 (4), 663-670.

Parfitt, R.L., 1989. Phosphate reactions with natural allophane, ferrihydrite and goethite. J. Soils Sci. 40, 359-369.

Pimentel, D., Levitan, L., 1986. Pesticides: amounts applied and amounts reaching pests. BioScience 36, 86-91.

Poeplau, C., Don, A., 2013. Sensitivity of soil organic carbon stocks and fractions to different land-use changes across Europe. Geoderma 192 (0), 189-201. http:// dx.doi.org/10.1016/j.geoderma.2012.08.003.

Provenzano, M.R., El, Bilali H., Simeone, V., Mondelli, D., Baser, N., 2011. Total sulphur contents over a three-year period in different organic vineyards of Apulia region, South-Eastern Italy. Italian J. Agron. 6, e27. http://dx.doi.org/ 10.4081/ija.2011.e27.

Quinton, J.N., Catt, J.A., 2007. Enrichment of heavy metals in sediment resulting from soil erosion on agricultural fields. Environ. Sci. Technol. 41, 3495-3500.

Quinton, J.N., Catt, J.A., Hess, T.M., 2001. The selective removal of phosphorus from soil: is event size important? J. Environ. Qual. 30, 538-545.

Rabiet, M., Margoum, C., Gouy, V., Carluer, N., Coquery, M., 2010. Assessing pesticide concentrations and fluxes in the stream of a small vineyard catchment - effect of sampling frequency. Environ. Pollut. 158, 737-748.

Rahman, M.A., Ishiga, H., 2012. Trace metal concentrations in tidal flat coastal sediments, Yamaguchi Prefecture, southwest Japan. Environ. Monit. Assess. 184, 5755-5771.

Rial-Otero, R., González-Rodríguez, R.M., Cancho-Grande, B., Simal-Gándara, J., 2004. Parameters affecting extraction of selected fungicides from vineyard soils. J. Agric. Food Chem. 52, 7227-7234.

Romić, M., Matijević, L., Bakić, H., Romić, D., 2014. Copper accumulation in vineyard soils: distribution, fractionation and bioavailability assessment. In: HernandezSoriano, M.C. (Ed.), Environmental Risk Assessment of Soil Contamination. http://dx.doi.org/10.5772/57086.

Rubaek, G.H., Kristensen, K., Olesen, S.E., Ostergaard, H.S., Heckrath, G., 2013. Phosphorus accumulation and spatial distribution in agricultural soils in Denmark. Geoderma 209, 241-250.

Rusjan, D., Strlič, M., Pucko, D., Korošec-Koruza, Z., 2007. Copper accumulation regarding the soil characteristics in Sub-Mediterranean vineyards of Slovenia. Geoderma 141, 111-118. 
Sabatier, P., Poulenard, J., Fanget, B., Reyss, J.-L., Develle, A.-L., Wilhelm, B., et al., 2014. Long-term relationships among pesticide applications, mobility, and soil erosion in a vineyard watershed. Proc. Natl. Acad. Sci. 111, 15647-15652. http:// doi.org/10.1073/pnas.1411512111.

Schreck, E., Geret, F., Gontier, L., Treilhou, M., 2008. Development and validation of a rapid multiresidue method for pesticide determination using gas chromatography-mass spectrometry: a realistic case in vineyard soils. Talanta 77, 298-303.

Shotbolt, L.A., Thomas, A.D., Hutchinson, S.M., 2005. The use of reservoir sediments as environmental archives of catchment inputs and atmospheric pollution. Prog. Phys. Geogr. 29, 337-361. http://dx.doi.org/10.1191/0309133305pp452ra. Shuman, L.M., 1988. Effect of organic matter on the distribution of manganese, copper, iron, and zinc in soil fractions. Soil Sci. 146, 192-198, 1988.

Stevanato, P., Concheri, G., Squartini, A., Saccomani, M., Piffanelli, P., Fricano, A., Angelini, E., Fornasier, F., 2014. Soil biological and Biochemical traits linked to nutritional status in grapevine. J. Soil Sci. Plant Nut. 14, 421-432.

Teixeira, C., Cândido de Medeiros, A., Peinador Fernandes, A., 1969. Carta Geológica Folha de Portugal à escala 1:50000, Folha 14-A Lamego. Notícia explicativa. Serviços Geológicos de Portugal, Lisboa.

Thevenon, F., Alencastro, L.Fd, Loizeau, J.-L., Adatte, T., Grandjean, D., Wildi, W., et al., 2013. A high-resolution historical sediment record of nutrients, trace elements and organochlorines (DDT and PCB) deposition in a drinking wate reservoir (Lake Brêt, Switzerland) points at local and regional pollutant sources. Chemosphere 90, 2444-2452.

Tibb, J., Gell, P., Hancock, G., Clark, M, 2010. Complex reservoir sedimentation revealed by an unusual combination of sediment records, Kangaroo Creek Reservoir, South Australia. J. Paleolimnol. 43, 535-549. http://dx.doi.org/ 10.1007/s10933-009-9349-0.

Tóth, G., Guicharnaud, R.-A., Tóth, B., Hermann, T., 2014. Phosphorus levels in croplands of the European Union with implications for $\mathrm{P}$ fertilizer use Eur J. Agron. 55, 42-52. http://dx.doi.org/10.1016/j.eja.2013.12.008.

Wang, T., Camps-Arbestain, M., Hedley, M., 2014. The fate of phosphorus of ash-rich biochars in a soil-plant system. Plant Soil 375, 61-74. http://dx.doi.org/ 10.1007/s11104-013-1938-z.

Wightwick, A.M., Mollah, M.R., Partington, D.L., Allinson, G., 2008. Copper fungicide residues in Australian Vineyard Soils. J. Agric. Food Chem. 56 (7), 2457-2464.

Yao, S.C., Xue, B., Tao, Y.Q., 2013. Sedimentary lead pollution history: lead isotope ratios and conservative elements at East Taihu Lake, Yangtze Delta, China. Quat. Int. 304, 5-12. 